\author{
УДК 94(571.1).05/.06 \\ О РОЛИ БИЙСКОЙ КРЕПОСТИ В РОССИЙСКОМ КОЛОНИЗАЦИОННОМ ПРОЦЕССЕ \\ НА АЛТАЕ В ПЕРВОЙ ПОЛОВИНЕ ХVІІ В. (К ЗО0-ЛЕТИЮ ВОЗВЕДЕНИЯ ВТОРОГО \\ БИКАТУНСКОГО ОСТРОГА)* \\ Денис С. Бобров ${ }^{a}$ @ \\ a Алтайский государственный университет, 656049, Россия, г. Барнаул, пр. Ленина, 61 \\ @BDS-eureka@yandex.ru
}

Поступила в редакиию 26.07.2017. Принята к печати 07.11.2018.

Ключевые слова: сибирские остроги, Бийская крепость, воеводы, приказчики, гарнизон острога, регулярные войска, Кузнецкий уезд

\begin{abstract}
Аннотация: Статья посвящена ревизии роли Бийской крепости в российском колонизационном процессе на Алтае посредством раскрытия места укрепления в административно-политическом процессе, протекавшем в Кузнецком уезде и в целом на юге Западной Сибири в конце XVII - середине XVIII вв. Источниковую основу исследования составили неопубликованные документы из фондов Российского государственного архива древних актов. Рассматриваются различные вопросы управления острогом: численность гарнизона и организация его снабжения, персоналии приказчиков, практика их взаимоотношений с кузнецкими воеводами и командирами регулярных воинских команд. Показано, как некоторые решения и действия уездных властей негативно сказывались на обороноспособности локального района. Выделены 4 этапа в истории Бийска первой половины XVIII в. и сделан вывод о приоритете административно-политического развития территориальной округи перед фортификационным строительством в освоенческом дискурсе местного уровня, а также о сочетании классических и гибридных стратегий, практик управления Бийской крепостью. Приведенные факты и суждения позволяют по-новому взглянуть на механизмы российской колонизации Алтая и южных районов Западной Сибири.
\end{abstract}

Для цитирования: Бобров Д. С. О роли Бийской крепости в российском колонизационном процессе на Алтае в первой половине XVIII в. (к 300-летию возведения второго Бикатунского острога) // Вестник Кемеровского государственного университета. 2018. № 4. С. 13-23. DOI: https://doi.org/10.21603/2078-89752018-4-13-23

\section{Введение}

Несмотря на кажущуюся изученность большинства сюжетов, феномен имперского продвижения России на восточные окраины и различные аспекты функционирования первых укреплений на линии авангарда колонизации до сих пор сохраняют ощутимый эвристический потенциал. В 2018 г. исполнилось 300 лет с момента возведения второго Бикатунского острога, что актуализирует вопрос ревизии роли этого объекта и со временем выросшей возле него административной округи в освоенческом процессе, который протекал в Верхнем Приобье в первой половине XVIII в.

Указ Петра I от 29 февраля 1708 г. о сооружении в верховьях Оби «острога со всякими крепостями» $[1$, c. $12 ; 2$, c. $13-14 ; 3$, c. 63,$66 ; 4$, c. $6 ; 5$, c. $12-13$; 6 , с. $41 ; 7$, с. $31 ; 8$, с. $91 ; 9$, с. $94-95]$ ознаменовал собой начало принципиально нового этапа российской колонизации юго-западных окраин Кузнецкого уезда и Алтая. Первое укрепление было возведено 18 июня 1709 г., однако спустя год оно было сожжено джунгарским отрядом во главе с зайсаном Духаром $[1$, c. $12 ; 2$, с. $14-17 ; 3$, с. $66-69 ; 4$, c. $6-9 ; 5$, с. $14-15$; 6 , с. $41-42 ; 7$, с. $31-42,44-46 ; 8$, с. $91 ; 9$, с. 94-97]. Несмотря на отсутствие прямых архивных свидетельств, но благодаря упоминанию Г. Ф. Миллера среди специалистов утвердилась точка зрения, согласно которой восстановление острога произошло в 1718 г. [1, с. $15 ; 2$, с. $21-22 ; 4$, с. $16 ; 5$, с. $15 ; 6$, с. 43 ; 7 , с. 49,$52 ; 8$, с. $91-92 ; 10$, с. 31-32], после чего «Бийская крепость» как административный объект уже не прекращала своего существования.

История Бикатунского острога освещена в научной литературе с различных, но близких друг другу подходов. В советский период специалисты делали исключительный акцент на организации походов в верховья Оби и сооружении укреплений 1709 и 1718 гг,, рассматривая эти процессы в контексте

* Публикация подготовлена при совместной финансовой поддержке РФФИ и Правительства Алтайского края в рамках реализации проекта № 17-11-22006. 
либо встраивания правительственного курса освоения в вольнонародную колонизацию, либо динамики гео- и этнополитической ситуации в регионе [1; 2, с. $3-24 ; 3$, с. $63-72 ; 4$, с. 3-17; 11; 12]. В 90-е гг. $\mathrm{XX}$ в. вектор исследований несколько сместился в сторону анализа военно-колонизационной политики Российского государства. Ее основные тенденции в отношении западносибирских пространств раскрыты в работах В. Д. Пузанова [13; 14]. В свою очередь, Бийскую крепость А. Ю. Огурцов и С. Р. Муратова рассматривают как часть сибирских укрепленных линий $[6$, с. $40-67 ; 10$, с. 31-34; 15]. Значимость Бийска как стратегического (опорного) пункта российских властей на Алтае в период первой половины - середины XVIII в. раскрыта историком-краеведом С. Ю. Исуповым, в том числе посредством выдвижения гипотезы относительно местоположения укрепления, реконструкции его внешнего облика и попытки проследить динамику численности гарнизона острога $[16$, с. 9-15; 17 , с. 11-21; 18, с. 95-96]. В ставших фактически итоговыми работах автор проводит мысль об эволюции роли Бийской крепости в военно-колонизационной политике России в предгорьях Алтая: от форпоста, служившего средством раннего оповещения о вторжении кочевников, до важного звена в системе оборонительных пограничных линий [7, с. 29-101; 8, с. 91-94]. В последние годы интерес к истории Бикатунского острога существенно снизился, что связано с достижением осязаемых пределов источниковой базы. Исключением из этого ряда является лишь монография В. Б. Бородаева и А. В. Контева, в которой авторы стремятся комплексно воссоздать первые дни укреплений в районе слияния Бии и Катуни [9, с. 89-101, 250-258], и ряд публикаций, в более или менее общей форме затрагивающих вопросы наглядно-графической фиксации Бийска как оборонительного и административного объекта на чертежах и картах XVIII в. [19, с. 36-43; 20, с. 112-114, $120-125 ; 21$, с. 45,47$]$. Таким образом, история Бикатунского острога рассмотрена в специальной и историко-краеведческой литературе в контексте развертывания военно-инженерной и фортификационной политики России, а также этно- и геостратегической ситуации на юге Западной Сибири.

В связи с этим целью статьи является анализ истории Бийской крепости первой половины XVIII в. в контексте административно-политического процесса, протекавшего в Кузнецком уезде и на Алтае. Источниковую основу исследования составили по большей части неопубликованные материалы фондов 248 (Сенат и его учреждения), 517 (Кузнецкая воеводская канцелярия) и 1402 (Бийская земская изба (Бийская крепость)) Российского государственного архива древних актов (РГАДА).
Строго формально оба фортификационных укрепления, сооруженные казаками в районе слияния Бии и Катуни в 1709 и 1718 гг. соответственно, являлись острогами, а не крепостями, и относились к административному ведению Кузнецкого уезда. В управленческом дискурсе Западной Сибири конца XVII - первой половины XVIII вв. строго не разводились понятия крепость и острог, часто они употреблялись вместе в одном документе в качестве синонимов, поэтому делопроизводственные материалы сохранили множество вариаций именований оборонительного объекта: Бийкатунская / Бикатунская / Бийская крепость / острог. Иногда встречалась конструкция «ведомство Бийской крепости». Категория ведомство в восприятии властей, служилых людей и крестьян XVIII в. обозначала принадлежность к той или иной территориальной округе, стратификацию подчинения властям определенного уровня, присуд.

\section{Приказчики в системе администрирования Бийского острога}

Управление Бикатунским острогом и относившейся к нему территории осуществлялось таким ординарным институтом гражданской системы управления, как приказчик. Соответствующая должность на протяжении первой половины XVIII в. замещалась кузнецкими служилыми людьми, в том числе детьми боярскими, авторитетными пешими или конными казаками (как правило, пятидесятниками или сотниками). К числу наиболее известных приказчиков Бийской крепости (по продолжительности отправления полномочий и количеству упоминаний в источниках) следует отнести Андрея Муратова, Федора Сорокина, Степана Серебреникова, Ивана и Степана Везигиных, Ивана Хабарова, Семена Гилева. Бийские приказчики являлись классическим проявлением годовальщиков в том плане, что командировались кузнецким воеводой в острог на определенное время [22, с. 132-133], по умолчанию на 1 год. В реальности этот срок практически никогда не соблюдался, а графики, равно как и периодичность ротации приказчиков и гарнизонных команд, не совпадали. Уездный центр декларировал и стремился реализовывать на практике полугодичную сменяемость служилых людей, направлявшихся в Бийск в первое время после учреждения здесь «обереговой службы». В свою очередь, по сведениям С. Ю. Исупова, первый бийский приказчик Андрей Попов передал управление острогом А. Муратову в мае 1710 г., т. е. по прошествии 11 месяцев замещения должности [7, с. 36]. По нашим данным в период с мая 1720 г. по октябрь 1721 г. в Бикатунской крепости в силу различных обстоятельств поочередно 
уступили место друг другу сразу три приказчика: Федор Сорокин, Иван Буткеев и Иван Везигин ${ }^{1}$.

Нормативной основой деятельности приказчиков становилась наказная память - особый вариант партикулярной персональной должностной инструкции, имевшей силу и характер распорядительного подзаконного нормативно-правового акта и адресованной лицу, вступавшему в соответствующую должность. В историко-краеведческой литературе утвердилась точка зрения, согласно которой основными функциями первых бийских управленцев являлись исполнительная и судебная [17, с. 12]. Конкретизируя этот тезис, хотелось бы подчеркнуть, что первая из них в реальности сводилась к оборонно-снабженческим, административно-хозяйственным и промульгационным аспектам. Между тем даже по мелким искам до 5 руб. источники не позволяют отследить реализацию де-юре предусмотренных наказной памятью² судебно-процессуальных компетенций приказчиков. С одной стороны, это может объясняться отсутствием установленной практики формальной фиксации мелких разбирательств. С другой - существенное число дел и решений по ним, выносившихся бийскими приказчиками на месте, так или иначе должно было породить недовольство отдельных лиц, которое, в свою очередь, неминуемо отразилось бы в архиве вышестоящих учреждений в виде жалоб воеводам. Однако соответствующие документы в фонде Кузнецкой воеводской канцелярии нам не известны. Скорее, правильно говорить о полицейской функции, заключавшейся в розыске, дознании, конвоировании и изредка осуществлении наказаний, вынесенных в уездном центре. Более подробно функционал приказчиков острогов и слобод Верхнего Приобья освещен в других наших работах [23, с. $145-166 ; 24$, с. 33-37].

Основными факторами обеспечения управления и обороноспособности Бийской крепости стала динамика отношений России с Джунгарским ханством и опасность агрессии последнего, а также ресурсный «голод», который испытывали приказчики на протяжении 10-30-х гг. XVIII в. Если первый аспект раскрыт в специальной литературе довольно полно [25, с. 9-148], то на проблеме ресурсного дефицита хотелось бы остановиться более подробно.

Гарнизон Бийской крепости и его численность

Вопрос о динамике численности гарнизона Бикатунского острога в первой половине XVIII в. является относительно слабо изученным и дискуссионным, несмотря на свою очевидную значимость и наличие отдельных публикаций, заглавие которых напрямую соотносится с ним [18, с. 95-96]. Существует историографическая константа относительно численности первого состава гарнизона Бийска в 100 человек $[1$, с. $12 ; 2$, с. $17 ; 3$, с. $67 ; 7$, с. 35-36, $42 ; 9$, с. 95,101$]$. Она основана на фразе из донесения кузнецкого воеводы Михаила Овцына в Москву о сооружении укрепления в верховьях Оби в 1709 г.: «а в оном новопостроенном остроге оставлен кузнецкий сын боярский Андрей Попов, а с ним служилых людей сто человек» [7, с. 35]. С. Ю. Исупов добавляет к этому, что в первые годы после восстановления укрепления (конец $10-\mathrm{X}$ - середина 20-х гг. XVIII в.) численность его гарнизона не превышала 50-60 человек [7, с. 52; 8, с. 92]. Этот тезис частично подтверждается фрагментом одной из редких коллективных челобитных кузнецких служилых людей сибирскому вице-губернатору Ивану Васильевичу Болтину от 5 ноября 1730 г., где отмечается, что «толко... ведомства Бийкатунской крепости для обережи оной крепости от неприятелских людей по пятидесят и шестидесят и до ста человек погодно также посылаемся» ${ }^{3}$. Таким образом, число годовальщиков, командировавшихся в Бийск, в случае усиления военно-политической напряженности в локальном районе могло возрастать до 100 казаков, что полностью соответствовало сложившимся административным практикам охраны крупных объектов Кузнецкого уезда. Вместе с тем снижение числа лиц, посылавшихся в Бикатунский острог, по сравнению с первыми годами после сооружения укрепления напрямую связано с началом строительства, а затем и введением в эксплуатацию Колыванских предприятий. В соответствии с решением вице-губернатора И. В. Болтина от 9 июля 1730 г. охрана промышленного комплекса А. Н. Демидова полностью ложилась на плечи служилых людей Кузнецкого уезда, причем предусматривалось выделение 60 казаков (до этого момента 40 казаков присылались из Томска и лишь 20 из Кузнецка) и потенциальное увеличение этого количества в летнее время до все тех же 100 человек [26, с. 24-25].

В результате в конце $20-x$ - начале $30-x$ гг. XVIII в. реальное число годовальных казаков в Бийской крепости опускалось до вовсе критического предела - 30-35 человек. Определенное улучшение ситуации произошло только в 1734 г., когда состав гарнизона возрос до 40 служилых людей ${ }^{4}$. При этом кузнецкие воеводы в силу отдаленности Бикатунского острога, нахождения его на периферии Кузнецкого уезда не всегда обладали точной информацией о числе командированных сюда

\footnotetext{
${ }^{1}$ РГАДА. Ф. 1402. Оп. 1. Д. 1. Л. 7-8 об., 21-23, 27-27 об., 44-44 об.

2 Там же, л. 7.

${ }^{3}$ РГАДА. Ф. 517. Оп. 1. Д. 26. Л. 33-33 об.

${ }^{4}$ РГАДА. Ф. 517. ОП. 1. Д. 51. Л. 11 об.-12.
} 
годовальщиков. Например, в своем доношении в Тобольскую губернскую канцелярию, которое впоследствии оказалось в Сенате, кузнецкий воевода Артем Федорович Бартенев сообщал о наличии в Бийске на момент 1734 г. 44 казаков, что являлось ощутимым преувеличением действительности ${ }^{5}$.

Вопрос о том, насколько 40-60 и даже 100 казаков могли справиться с потенциальной угрозой набега и разорения со стороны калмыков и их кыштымников - открытый, учитывая, что более 60 служилых не смогли сохранить крепость в 1710 г. Для сравнения Г. Ф. Быконя приводит данные о приблизительно 400 служилых, находившихся на годовальной службе в Абаканском остроге в конце первого десятилетия XVIII в. [27, с. 80-81]. Ресурсы, которыми располагала Кузнецкая воеводская канцелярия, были значительно скромнее: к середине 30-х гг. XVIII в. общее число служилых людей (т. е. нерегулярных соединений), приписанных к Кузнецку, составляло 500 человек, 328 (65,6 \%) из которых находились в различных командировках как на территории уезда, так и за его пределами 6 . Это значительно превышало средний по Западной Сибири процент служилых людей в «дальних отлучках», который составлял примерно треть [28, с. 23].

Персонификация управления как синдром и ее влияние на локальный административный процесс

Персонификация управления, ставшая неизбежным следствием распространения на территорию Верхнего Приобья общероссийской тенденции бюрократического централизма, для Бийской крепости имела как положительные, так и негативные моменты. С одной стороны, на локальном уровне концентрация и замыкание максимума полномочий на одном лице позволяли оперативно организовывать ограниченные ресурсы для решения определенной поставленной задачи. С другой стороны, любые сомнительные, а уж тем более преступные действия приказчиков приводили не только к подрыву авторитета государственной власти в административной округе, но и ставили под угрозу безопасность острога. Возможно, в связи с этим примеров совершенных бийскими приказчиками преступлений не так много.

Заслуживает внимания один вопиющий факт. На рубеже 1729-1730 гг. «началный человек» Бий- ской крепости С. Везигин за взятки отпустил в «домы свои», т.е. в окрестности Кузнецка, 23 служилых человека из 30, составлявших годовальную гарнизонную команду ${ }^{7}$ Посланный кузнецким воеводой Петром Нефедеевым изначально с совершенно иными целями Федор Крячиков был настолько изумлен коррумпированностью приказчика и его пренебрежением задачами обороны острога, что с ужасом писал воеводе: «а на обереговой службе в той крепости служилых людей почти не осталось» ${ }^{8}$. Далее Ф. Крячиков также констатировал, что уже в течение года С. Везигин тормозил любые финансовые платежи из Бийска в Кузнецк. Примечательно, что воеводу заинтересовал именно последний аспект, а не тот катастрофический ущерб обороноспособности локального района, который был причинен действиями приказчика. П. Нефедеев инициировал следствие над С. Везигиным. Вина последнего не вызывала особых сомнений. Выяснилось, что из подвала земской избы были украдены все казенные деньги, в то время как приказчик снял с него охрану, мотивируя это дальностью расположения жилищ служилых людей от места несения караула. Более того, С. Везигин придумал себе наивное алиби: якобы во время ограбления он ночью «уходил в чесовню молиться Богу», а «присылной» Яков Волков показывал, что вскоре после преступления нашел приказчика «в чесовне, и горит свеча» ${ }^{9}$. При всех этих, казалось бы, однозначных обстоятельствах П. Нефедеев оправдал приказчика и возложил вину в краже денег на целовальника Ивана Бызова ${ }^{10}$.

Действия уездного администратора выглядели явным укрывательством, т. к. еще в 1728 г. при вступлении того же С. Везигина в должность его предшественник Иван Шебалин в доношении в Кузнецк подчеркивал, что прибывший сменщик заставил его собирать подушные деньги уже после передачи «укасов и алтирелских припасов» (т.е. фактически после прекращения полномочий $)^{11}$. Более того, С. Везигин, не предъявив какого-либо воеводского указа, санкционировавшего подобные действия, фактически силой забрал у И. Шебалина 6 руб. Наконец, бывший приказчик обращал внимание воеводы на факт публичной взятки, полученной С. Везигиным от служилого Алексея Сидорова, за освобождение от несения реальной «обереговой» службы ${ }^{12}$. Доношение И. Шебалина не привлекло внимание воеводы, точно

\footnotetext{
${ }_{5}^{5}$ РГАДА. Ф. 248. Оп. 15. Кн. 867. Д. 1. Л. 668-670.

${ }^{6}$ РГАДА. Ф. 517. Оп. 1. Д. 51. Л. 12-12 об.

7 РГАДА. Ф. 517. Оп. 1. Д. 19. Л. 51-58.

${ }^{8}$ Там же, л. 51-52.

${ }^{9}$ Там же, л. 99-101.

${ }^{10}$ Там же, л. 103-104.

${ }^{11}$ РГАДА. Ф. 517. Оп. 1. Д. 16. Л. 1-1 об.

12 Там же, л. 1 об.
} 
так же как и жалоба жителя Бикатунской крепости Кирилла Соколова касательно того, что ему только путем взятки в 7 руб. удалось откупиться от рекрутского набора в 1729 г. ${ }^{13}$

После инцидента с С. Везигиным уездное начальство все же стало внимательнее относиться к деятельности приказчиков и временами даже «придираться» к ним. Однако, на наш взгляд, динамика политического курса Кузнецка в отношении администраторов Бийской крепости в условиях уже упоминавшейся персонификации власти напрямую была связана с личностью конкретного главы уезда. В этом свете отношения по линии «П. Нефедеев - С. Везигин» резко контрастируют с инцидентом, произошедшим в конце 1733 - начале 1734 гг.

Воевода А. Ф. Бартенев направил служилого Ивана Саратова в Бикатунский острог для ареста и конвоирования в Кузнецк «началного человека» Ивана Буткеева. Резкое недовольство уездного центра вызвало промедление приказчика в вопросе высылки подозревавшейся в колдовстве «бабы Акулины». И. Саратову напрямую предписывалось «взяв ис той крепости... с лошадю и со збруей прикащика Буткеева, и привесть в Кузнецк и обявить при доношении в Кузнецкую канцелярию, також и бабу Акулину, заковав в ручныя и ножныя кондалы» ${ }^{14}$. Однако к моменту прибытия экспедиционно-конвойной команды И. Буткеев уже отправил Акулину в Кузнецк. Тем самым формальные основания поспешной высылки приказчика в уездный центр отпали, т.к. это напрямую угрожало обороноспособности крепости, являвшейся важным порубежным фронтирным форпостом на юге Западной Сибири. Однако в силу априорной и, как следствие, в чем-то даже слепой императивности любого решения воеводы И. Саратов не посмел отступить от буквы указа. В результате в марте 1734 г. И. Буткеев под конвоем отправился в Кузнецк, а «Бийская крепость приказана служилым Максиму Ананину да крестьянину Абраму Исакову» ${ }^{15}$.

А. Ф. Бартенев, безусловно, мог предусмотреть различные варианты развития событий и в указе (памяти) И. Саратову прописать элементы диспозитивного (предусматривающего выбор альтернатив) поведения, но этого не сделал. Как в случае с С. Везигиным, так и с И. Буткеевым воеводы за весь период следствия фактически так и не озаботились проблемами самой Бийской крепости, остававшейся в непростых реалиях пограничья на относительно длительное время без приказчика, а иногда и фактически без гарнизона. Временно «порученными» на период разбирательства над «началным челове- ком» становилась импровизированная группа / коллегия из 2-3 человек, большую часть из которых составляли крестьяне. Несмотря на рудиментарный характер такой практики стоит отметить, что она являлась отражением подмеченной Н. А. Миненко тенденции поиска оптимальной модели организации и функционирования локальных звеньев системы управления конца XVII - начала XVIII вв. [29, c. 11]. Однако в реалиях административно-правовой системы Российского государства первой половины XVIII в. корпоративное руководство не имело почти никаких нормативных оснований и рассматривалось местным населением лишь в качестве временной меры, в результате чего «порученным» откровенно слабо подчинялись даже крестьяне и уж тем более служилые люди. Стремление уездных властей следовать установившимся управленческим практикам приводило к поддержанию должного уровня административного процесса, но часто ценой этого становилось катастрофическое снижение обороноспособности Бийской крепости. Однако из этой тенденции были и исключения. Например, тот же А. Ф. Бартенев в 1736 г. первым из кузнецких воевод лично проинспектировал Бикатунскую крепость, оценил состояние ее гарнизона и укреплений, а также выдал приказчику несколько локальных предписаний ${ }^{16}$.

\section{Управление Бийским острогом в контексте трансформации региональной административ- ной парадигмы}

Невозможность организации эффективной обороны на юге Западной Сибири осознавалась центральными и региональными властями и в конечном итоге в совокупности с возобновившимися претензиями со стороны джунгарских зайсанов и алманщиков стала важным фактором ощутимой региональной административной перестройки во второй половине 30-х - начале 40-х гг. XVIII в. Изменения вылились не только в штатную реформу казачества, но и в создание в дополнение к четырем уже существовавшим в Сибири полкам Новоучрежденного драгунского, а также Новоучрежденного пехотного батальона [28, с. 22-27; 30, с. 64-77]. Бийскую крепость эти перемены задели самым ощутимым образом. В 1738 г. сюда из Кузнецка была направлена рота только что образованного полка под командованием поручика Петра Фадеева [7, с. 60-61; 8, с. 93; 38, с. 77], которому предписывалось всеми силами не допустить разорения юго-западных окраин Кузнецкого уезда, для чего определялось драгун и казаков «никуда не роспускать и иметь в крепо-

\footnotetext{
${ }^{13}$ РГАДА. Ф. 517. ОП. 1. Д. 25. Л. 60.

${ }^{14}$ РГАДА. Ф. 517. ОП. 1. Д. 51. Л. 7.

15 Там же.

${ }^{16}$ РГАДА. Ф. 517. Оп. 1. Д. 68. Л. 14.
} 
сти [Бийской] денно и нощно отъезжие караулы, как воинский артикул повелевает» [6, с. 48]. В подчинении у П. Фадеева находились 100 человек из регулярных воинских подразделений (30 из которых он сразу должен был отправить в Белоярск) и 50 кузнецких казаков под командованием пятидесятника Тимофея Бессонова [6, с. 48]. Таким образом, Бийская крепость еще в конце $30-$ х гг. XVIII в. стала одной из ведущих площадок на юге Западной Сибири, где апробировалось сочетание способов насыщения крепостного гарнизона: иррегулярными и регулярными воинскими частями.

Между тем полковые соединения, направлявшиеся в Бийск, подлежали ротации (а не находились здесь стационарно расквартированными, как считают многие исследователи), что сближало их с годовальщиками, однако период службы в «ведомстве Бийской крепости» у первых был несравнимо больше. В начале 40-х гг. XVIII в. в округу Бийска была переброшена воинская команда во главе с капитаном Василием Соколовым, который получил указ подчиняться Кузнецкой воеводской канцелярии «без всякаго отрицания и прекословия» ${ }^{17}$. При этом изначальное число регулярных военных (100 человек), посылавшихся в Верхнее Приобье, постепенно пересматривалось в сторону увеличения: в 1743 г. в Бийской крепости на постоянной основе находились 64 драгуна и солдата (в Белоярской крепости - 56, т. е. в общей сложности 110$)^{18}$, а к 1744 г. суммарное число офицеров и солдат только в Бийске возросло до 85 человек ${ }^{19}$, в 1745-1746 гг. превысило 200. В результате административных решений конца $30-\mathrm{x}$ - начала 40-х гг. XVIII в. Бийская крепость получила существенное ресурсное насыщение в виде регулярных воинских частей, что, безусловно, повышало обороноспособность укрепления и ощутимым образом снижало нагрузку с команд служилых людей, но с другой - ставило вопрос о разграничении полномочий между приказчиками и военными командирами, а также об организации снабжения вверенных последним подразделений.

С. Ю. Исупов рисует эволюционную по своему характеру картину, когда «на смену казачьим приказчикам приходят новые, "регулярные" гарнизонные командиры, управлявшие крепостью с помощью "канцелярии полковых дел"» [17, с. 15]. Но это утверждение справедливо лишь для второй половины 40-х гг. XVIII в., когда начинается сле- дующая, более явная фаза административной перестройки. В конце 30-х - начале 40-х гг. приказчики и командиры расквартированных в Бийске полковых рот сосуществовали вместе, так или иначе частично разделяя свой функционал.

Наиболее важным в этом свете становился вопрос снабжения гарнизонных команд. Резолюция Кабинета министров о создании Новоучрежденного полка предполагала среди прочего «провиантом их ${ }^{20}$ доволствовать и на лошадей овес употреблять из десятинного хлеба» [30, с. 74]. В реалиях Кузнецкого уезда воеводская канцелярия фактически полностью переложила решение этой задачи на плечи приказчиков.

В условиях немногочисленности населения в административной округе Бийска изначально планировалось направлять провизию из богатой сельскохозяйственными угодьями Малышевой слободы, что вызвало массовые протесты податного населения, вылившиеся в фактический саботаж доставки четверикового провианта в Бикатунскую крепость. В коллективной челобитной воеводе крестьяне в резкой форме подчеркивали невозможность соответствующих операций в силу приписки значительного числа населения к Колыванским заводам $^{21}$. В ответ на это уездный администратор Андрей Герасимович Шапошников предписал приказчику Бикатунской крепости Тимофею Шестакову: «а как ли из Малышевой слободы того правианта и поныне в Бийск не привесено, то да привосу того провианта взять у бийских обывателей заимообрасно, а по привосе тот правиант из Малышевской ${ }^{22}$ правианта отдать возвратно немедленно» ${ }^{23}$. Таким образом, речь шла об обязанности приказчика частично изымать хлеб у поднадзорных ему крестьян вплоть до соответствующих поставок. Административная практика показывала, что такие задержки могли достигать 2-3 лет, что, в свою очередь, порождало ощутимые недовольства в крестьянской среде жителей Бийской крепости. Тем не менее состояние неурегулированности вопросов снабжения, характерное для первых лет функционирования в Верхнем Приобье регулярных частей, относительно быстро сгладилось за счет эволюции управленческого подхода. Уже в 1744 г. все тот же А. Г. Шапошников отправил бийскому приказчику 100 руб., предписав «в нынешнее время купит в Бийску у бийскаго ведомства в деревнях на дачю обретающимся в Бийску на фарпостах... провианту

\footnotetext{
${ }^{17}$ РГАДА. Ф. 1402. ОП. 1. Д. 4. Л. 38 об.

${ }^{18}$ РГАДА. Ф. 517. Оп. 1. Д. 119. Л. 3 об.

${ }^{19}$ РГАДА. Ф. 1402. Оп. 1. Д. 4. Л. 27.

${ }^{20}$ офицеров и солдат Новоучрежденного полка и Новоучрежденного пехотного батальона.

${ }^{21}$ РГАДА. Ф. 517. Оп. 1. Д. 119. Л. 1-1 об.

22 слободы.

${ }^{23}$ РГАДА. Ф. 517. Оп. 1. Д. 140. Л. 1 об.
} 
муки ржаной самою настоящею ценою... и оной по требованию обретающегося в том бийском фарпосте командира ${ }^{24}$ производит помесячно в дачю без всякаго задержания» ${ }^{25}$. Однако даже после этой меры тема обеспечения провизией регулярных частей, располагавшихся в окрестностях Бийска, не была полностью закрыта. Показательным в этом отношении является направленное В. Соколовым приказчику С. Гилеву требование, в котором напрямую указывалось на промедления последнего в закупках провианта и на право капитана «усилно принуждать» в случае отсутствия позитивной динамики решения вопроса ${ }^{26}$. К этому следует добавить регулярные требования воевод на протяжении 1744-1745 гг. возводить «крепкие строения для провианта и фуража», в том числе «три провиантских амбара», а также отправку из Кузнецка служилых людей для описи провианта в «ведомстве Бийской крепости» ${ }^{27}$.

\section{Бийский острог и его округа}

Бикатунский острог первой половины XVIII в. немыслим без своей округи, которая в 2040-е гг. столетия представляла собой конгломерат до 5-6 небольших деревень с пестрой территориальной локализацией. По сведениям Ю. С. Булыгина, в 1724 г. «в ведомстве Бикатунской крепости» были учтены 72 человека, в то время как к середине 40-х гг. число жителей достигло 258 [1, с. 36, 47]. Немногочисленность населения, значительную долю которого составляли маргиналы, обуславливала откровенно слабое развитие институтов крестьянского самоуправления. Первые отложившиеся в документах упоминания о выборах старост и целовальников из крестьянской среды относятся только к 1731 г. ${ }^{28}$ В этом свете Бийск XVIII в. можно назвать классическим фронтирным острогом, стоявшим на границе освоенных государством и неосвоенных земель. Поэтому для определенных людей Бийская крепость служила своего рода притягательным маяком. Например, в обращении к кузнецкому воеводе служилый Борис Бирюков отмечал, что его сын Иван еще в 1719 г. самовольно ушел в Бийск и не хотел возвращаться ${ }^{29}$. Острог на юго-западной окраине Кузнецкого уезда довольно быстро превратился в заманчивое место для одних и максимально непривлекательное для других. Примечателен случай, произошедший с жителями Мунгатского станца в середине 20-х гг. XVIII в. Большая группа крестьян отказалась переселяться в округу Бийска, несмотря на то что ранее они просили об этом и получили соответствующую санкцию. Другая часть населения этого же административного пункта наоборот стремилась «отговориться» от рекрутского набора тем, что «определены» к поселению в укрепление на слиянии Бии и Катуни ${ }^{30}$. Сами местные жители видели в Бийской округе опорную площадку для ведения хозяйственной деятельности в приграничной зоне. Крестьяне часто уходили «в степь», иногда даже с санкции или по воле приказчика. В большинстве случаев такие отлучки заканчивались мирно и без эксцессов, но бывали и исключения. Так, в середине 20-Х гг. XVIII в. 70 крестьян «ведомства Бийской крепости» во главе с Козьмой Опенышевым отправились для бугрования в район Таутелеутской волости и Каракола, где наткнулись на 12 калмыков, 11 из которых убили ${ }^{31}$.

\section{Заключение}

В первой половине XVIII в. Бийск прошел существенный путь эволюции: от острога малого чина до одного из ведущих районов Алтая и южных областей Западной Сибири. В административно-политической истории Бийской крепости этого периода времени можно выделить 4 этапа. Первый охватил короткий промежуток 1709-1710 гг. и сохранил о себе чрезвычайно мало сведений. Следующий связан с восстановлением острога в районе слияния Бии и Катуни и продолжался вплоть до середины 30-х гг. XVIII в., это время начальной институционализации властных структур, а также первых опытов выстраивания системы управления и коммуникации между воеводами и приказчиками. Начиная с этого периода в локальной освоенческой повестке административно-политическое развитие стало очевидно превалировать над фортификационным строительством. Третий этап продолжался с середины 30-х до середины 40-х гг. и заключался в плавном изменении реализовывавшихся стратегий и внедрявшихся практик за счет насыщения крепости регулярными воинскими подразделениями. Наконец, четвертый временной отрезок начался с середины 40-х гг. и представлял собой более кардинальную перестройку вертикали власти, когда Бийск стал одним из важных центров в системе складывавшихся

\footnotetext{
${ }^{24}$ В. Соколова.

${ }^{25}$ РГАДА. Ф. 1402. ОП. 1. Д. 4. Л. 27 об.

26 Там же, л. 48-48 об.

${ }^{27}$ РГАДА. Ф. 1402. ОП. 1. Д. 5-а. Л. 80-82, 178.

${ }^{28}$ РГАДА. Ф. 1402. Оп. 1. Д. 1-а. Л. 11-13.

${ }^{29}$ РГАДА. Ф. 517. Оп. 2. Д. 13. Л. 111.

${ }^{30}$ РГАДА. Ф. 517. Оп. 2. Д. 12. Л. 12.

${ }^{31}$ РГАДА. Ф. 517. ОП. 2. Д. 7. Л. 43.
} 
сибирских укрепленных линий. В целом следует говорить о том, что Бийская крепость в первой половине XVIII в. оказалась на линии авангарда милитарной модернизации, став площадкой апробации классических, а также синтезных и гибридных административных моделей и способов их воплощения.

\section{Литература}

1. Булыгин Ю. С. Первые крестьяне на Алтае. Барнаул: Алт. кн. изд-во, 1974. 144 с.

2. Булыгин Ю. С. Выход русских к реке Бии и основание Бикатунской крепости // Города Алтая эпохи феодализма и капитализма: межвуз. сб. науч. ст. Барнаул: Изд-во АГУ, 1986. С. 3-24.

3. Уманский А. П. 285 лет Бикатунской крепости // Страницы истории Алтая 1994 г.: библиографический указатель. Барнаул, 1993. С. 63-72.

4. Уманский А. П. Кузнецк и Алтайские остроги // Кузнецкая старина. 1999. Вып. 3. С. 3-17.

5. Исупов С. Ю. Бийск: острог, крепость, город. Бийск: НИЦ БПГИ, 1999. 151 с.

6. Огурцов А. Ю. На Кузнецкой линии // Кузнецкая старина. 2007. Вып. 9. С. 40-67.

7. Исупов С. Ю. Крепость Бийская есть главная... Барнаул: Азбука, 2009. 302 с.

8. Исупов С.Ю. Роль Бийской крепости в военно-колонизационной политике Российской империи на Алтае в первой половине XVIII в. // Известия Алтайского государственного университета. 2010. № 4-3. С. 91-94.

9. Бородаев В. Б., Контев А. В. Формирование российской границы в Иртышско-Енисейском междуречье в 1620-1720-х гг. Барнаул: Изд-во АлтГПУ, 2015. 415 с.

10. Муратова С. Р. Сибирские укрепленные линии в XVIII в.: дис. ... канд. ист. наук. Уфа, 2007. 241 с.

11. Сергеев А. Д. Тайны алтайских крепостей. Барнаул: Алт. кн. изд-во, 1975. 80 с.

12. Уманский А. П. Телеуты и русские в XVII-XVIII вв. Новосибирск: Наука, 1980. 296 с.

13. Пузанов В. Д. Военные факторы русской колонизации Западной Сибири (конец XVI - начало XVIII в.): автореф. дис. ... д-ра. ист. наук. М., 2010. 49 с.

14. Пузанов В. Д. Военная политика Русского государства в Западной Сибири (конец XVI - начало XVIII в.). Сургут: Таймер, 2011. 233 с.

15. Огурцов А. Ю. Военно-инженерная политика России на юге Западной Сибири в XVIII в.: автореф. дис. ... канд. ист. наук. Свердловск, 1990. 23 с.

16. Исупов С. Ю. К вопросу о месте сооружения Бикатунского острога 1709 г. // Краеведческий вестник (историко-публицистический альманах БКМ им. В. В. Бианки). 1998. Вып. 8. С. 9-15.

17. Исупов С. Ю. Приказчики и коменданты Бийской крепости // Бийские градоначальники: исторические очерки. Бийск: Типография БПГУ, 2002. С. 11-21.

18. Исупов С. Ю. Динамика изменений численности гарнизона Бийской крепости в первой половине XVIII в. // Актуальные вопросы истории Сибири. Восьмые науч. чтения памяти проф. А. П. Бородавкина / под ред. В. А. Скубневского, К. А. Пожарской. Барнаул: Изд-во АГУ, 2011. С. 95-96.

19. Контев А. В. Русские крепости Алтая на картах и чертежах XVIII в. // Вопросы истории фортификации. 2010. № 1. С. 36-43.

20. Соболева Т. Н., Афанасьев П. А., Кухаренко А. Е., Бобров Д. С. Эксплуатация природных ресурсов Алтая императорским Кабинетом как фактор развития российской монархии (XVIII - начало XX в.). Барнаул: Азбука, 2012. 260 с.

21. Историко-географические образы Алтая в трудах ученых, путешественников и чиновников XVIII начала XX в. / под ред. Т. Н. Соболевой, Д. С. Боброва. Барнаул: Азбука, 2016. 440 с.

22. Пузанов В. Д. Годовальщики в Сибири в XVII в. // Вопросы истории. 2009. № 2. С. 132-142.

23. Бобров Д. С. Политико-правовые механизмы освоения Российским государством Верхнего ОбьИртышья (Алтая) в первой половине XVIII в.: дис. ... канд. ист. наук. Барнаул, 2017. 252 с.

24. Бобров Д. С. Приказчики острогов и слобод Верхнего Приобья как системообразующие институты локального звена системы управления регионом в 20-30-х гг. XVIII в. // Известия Алтайского государственного университета. 2016. № 2. С. 33-37. DOI: 10.14258/izvasu(2016)2-04

25. Моисеев В. А. Россия и Джунгарское ханство в XVIII в. (очерки внешнеполитических отношений). Барнаул: Изд-во АГУ, 1998. 174 с.

26. Бобров Д. С. Колыванские заводы в политике кузнецких воевод во второй четверти XVIII в. // Вестник Кемеровского государственного университета. 2017. № 4. C. 23-29. DOI: 10.21603/2078-8975-2017-4-23-29

27. Быконя Г. Ф. Заселение русскими Приенисейского края в XVIII в. 2-е изд., доп., осуществленное по первой авторской редакции. Красноярск: КГПУ им. В. П. Астафьева, 2013. 1 электрон. опт. диск (CD-ROM).

28. Зуев А. С. Штатная реформа сибирского казачества 1737 г. // Вестник Новосибирского государственного университета. Серия: история, филология. 2007. Т. 6. № 1. С. 22-27. 
29. Миненко Н. А. Русская крестьянская община в Западной Сибири. XVIII - первая половина XIX в. Новосибирск: Изд-во Новосиб. ун-та, 1991. 265 с.

30. Дмитриев А. В. Русская регулярная армия в Сибири (1725-1796 гг.): дис. ... д-ра ист. наук. Новосибирск, 2018. 439 с.

\title{
ABOUT THE ROLE OF THE BIYSK FORTRESS IN THE RUSSIAN COLONIZATION PROCESS IN THE ALTAI IN THE FIRST HALF OF THE XVIII CENTURY (TO THE 300TH ANNIVERSARY OF THE ERECTION OF THE SECOND BIYSK STOCKADED TOWN)* \\ Denis S.Bobrov ${ }^{a}$ @
}

\author{
a Altai State University, 61, Lenina ave., Barnaul, Russia, 656049 \\ @BDS-eureka@yandex.ru
}

Received 26.07.2017. Accepted 07.11.2018.

Keywords: Siberian stockaded towns, Biysk fortress, vaivodes, clerks, garrison of the stockaded town, active forces, Kuznetsk uyezd

\begin{abstract}
The article features the role of the Biysk Fortress in the Russian colonization process in the Altai reagion. The author revealed the place of the Fortress in the administrative and political process which took place in the Kuznetsk province and generally in the South of Western Siberia in the end of the XVII - the middle of the XVIII century. The research was based on unpublished documents from the funds of the Russian State Archive of Ancient Acts. The research involved various problems of the stockaded town, i.e. the number of soldiers in the garrison and its supply organization, the identity of its clerks and their relations with Kuznetsk commanders and staff officers of regular military groups. The article shows that some decisions and actions of the county authorities had a negative influence on the defensive capacity of the fortress. The author identified four stages in the Biysk Fortress history of the first half of the XVIII century and recognizes the priority of the administrative and political development over the fortification building in the management discourse at the local level. The author also highlighted the combination of classical and hybrid strategies and the Biysk Fortress management practices. The given facts make it possible to take a fresh look at the mechanisms of the Russian colonization of the Altai and the southern regions of Western Siberia.
\end{abstract}

For citation: Bobrov D. S. O roli Biiskoi kreposti v rossiiskom kolonizatsionnom protsesse na Altae v pervoi polovine XVIII v. (k 300-letiiu vozvedeniia vtorogo Bikatunskogo ostroga) [About the Role of the Biysk Fortress in the Russian Colonization Process in the Altai in the First Half of the XVIII Century (to the 300th Anniversary of the Erection of the Second Biysk Stockaded Town)]. Bulletin of Kemerovo State University, no. 4 (2018): 13-23. DOI: https://doi.org/10.21603/2078-8975-2018-4-13-23

\section{References}

1. Bulygin Iu. S. Pervye krest'iane na Altae [First peasants in the Altai]. Barnaul: Alt. kn. izd-vo, $1974,144$.

2. Bulygin Iu. S. Vykhod russkikh k reke Bii i osnovanie Bikatunskoi kreposti [The Russians' exit to the river Biya and foundation of the Bikatun Fortress]. Goroda Altaia epokhi feodalizma i kapitalizma [Cities of the Altai in the period of feudalism and capitalism]. Barnaul: Izd-vo AGU, 1986, 3-24.

3. Umanskii A. P. 285 let Bikatunskoi kreposti [285 years of Bikatun fortress]. Stranitsy istorii Altaia 1994 g.: bibliograficheskii ukazatel' [Pages of Altai history 1994: bibliographic index]. Barnaul, 1993, 63-72.

4. Umanskii A. P. Kuznetsk i Altaiskie ostrogi [Kuznetsk and Altai fortifications]. Kuznetskaia starina [Kuznetsk antiquity], Iss. 3 (1999): 3-17.

5. Isupov S. Yu. Biisk: ostrog, krepost', gorod [Biysk: stockaded town, fortress, city]. Biisk: NITS BPGI, $1999,151$.

\footnotetext{
* The publication was prepared with the joint financial support of the Russian Federal Property Fund and the Government of the Altai Territory in the framework of the project No. 17-11-22006.
} 
6. Ogurtsov A. Iu. Na Kuznetskoi linii [On the Kuznetsk Line]. Kuznetskaia starina [Kuznetsk antiquity], Iss. 9 (2007): 40-67.

7. Isupov S. Yu. Krepost' Biiskaia est' glavnaia... [The Biysk fortress is the most important one...]. Barnaul: Azbuka, 2009, 302.

8. Isupov S. Yu. Rol' Biiskoi kreposti v voenno-kolonizatsionnoi politike Rossiiskoi imperii na Altae v pervoi polovine XVIII v. [Significance of the Bijsk Fortress in military and colonization policy of the Russian Empire in the Altay in the 1 st half of xviii century]. Izvestiia Altaiskogo gosudarstvennogo universiteta = Izvestiya of Altai State University Journal, no. 4-3 (2010): 91-94.

9. Borodaev V. B., Kontev A. V. Formirovanie rossiiskoi granitsy v Irtyshsko-Eniseiskom mezhdurech'e $v$ 1620-1720-kh gg. [The formation of the Russian state border in Irtysh-Yenisei interfluve area in 1620-1720]. Barnaul: Izd-vo AltGPU, 2015, 415.

10. Muratova S. R. Sibirskie ukreplennye linii v XVIII v. Diss. kand. ist. nauk [Siberian fortified lines in the XVIII century. Cand. Hist. Sci. Diss.]. Ufa, 2007, 241.

11. Sergeev A. D. Tainy altaiskikh krepostei [Secrets of the Altai fortresses]. Barnaul: Alt. kn. izd-vo, $1975,80$.

12. Umanskii A. P. Teleuty i russkie $v$ XVII-XVIII vv. [Teleuts and Russians in the XVII-XVIII centuries]. Novosibirsk: Nauka, 1980, 296.

13. Puzanov V. D. Voennye faktory russkoi kolonizatsii Zapadnoi Sibiri (konets XVI - nachalo XVIII v.). Avtoref. diss. doktora ist. nauk [Military factors of the Russian colonization of Western Siberia (the end of the 16 th - the beginning of the 18th century). Dr. Hist. Sci. Diss. Abstr.]. Moscow, 2010, 49.

14. Puzanov V. D. Voennaia politika Russkogo gosudarstva v Zapadnoi Sibiri (konets XVI - nachalo XVIII v.) [The military politic of the Russian state in Western Siberia (late XVI - early XVIII century)]. Surgut: Taimer, 2011, 233.

15. Ogurtsov A. Iu. Voenno-inzhenernaia politika Rossii na iuge Zapadnoi Sibiri v XVIII v. Avtoref. diss. kand. ist. nauk [Military and engineering politic of Russia in the south of Western Siberia in the XVIII century. Cand. Hist. Sci. Diss. Abstr.]. Sverdlovsk, 1990, 23.

16. Isupov S. Yu. K voprosu o meste sooruzheniia Bikatunskogo ostroga $1709 \mathrm{~g}$. [To the issue of the situation of the Bikatun stockade town in the 1709]. Kraevedcheskii vestnik (istoriko-publitsisticheskii al'manakh BKM im. V. V. Bianki) = Local history bulletin (historical and journalistic almanac BKM named after V. V. Bianki), Iss. 8 (1998): 9-15.

17. Isupov S. Yu. Prikazchiki i komendanty Biiskoi kreposti [Clerks and commandants of the Biysk Fortress]. Biiskie gradonachal'niki: istoricheskie ocherki [Biysk governors: historical essays]. Biisk: Tipografiia BPGU, 2002, 11-21.

18. Isupov S. Yu. Dinamika izmenenii chislennosti garnizona Biiskoi kreposti v pervoi polovine XVIII v. [Dynamics of changes in the number of the Biysk fortress garrison in the first half of the 18th century]. Aktual'nye voprosy istorii Sibiri. Vos'mye nauch. chteniia pamiati prof. A. P. Borodavkina [Major issues of the history of Siberia. 8th scientific reads in memory of prof. A.A. Borodavkin]. Eds. Skubnevskii V. A., Pozharskaia K. A. Barnaul: Izd-vo AGU, 2011, 95-96.

19. Kontev A. V. Russkie kreposti Altaia na kartakh i chertezhakh XVIII v. [Russian fortresses of Altai on maps and drawings of the XVIII century]. Voprosy istorii fortifikatsii = History of fortification questions, no. 1 (2010): 36-43.

20. Soboleva T. N., Afanasiev P. A., Kukharenko A. E., Bobrov D. S. Ekspluatatsiia prirodnykh resursov Altaia imperatorskim Kabinetom kak faktor razvitiia rossiiskoi monarkhii (XVIII - nachalo XX v.) [Exploitation of natural resources by the Imperial Cabinet as a factor of the Russian monarchy development (XVIII - early XX century)]. Barnaul: Azbuka, 2012, 260.

21. Istoriko-geograficheskie obrazy Altaia $v$ trudakh uchenykh, puteshestvennikov $i$ chinovnikov XVIII nachala XXv. [Historical and geographical Altai images in scientists', travelers' and officials' scholary works of XVIII - early XX century]. Eds. Soboleva T. N., Bobrov D. S. Barnaul: Azbuka, 2016, 440.

22. Puzanov V. D. Godoval'shchiki v Sibiri v XVII v. [Godovalchsici in Siberia in the XVII century]. Voprosy istorii $=$ Questions of History, no. 2 (2009): 132-142.

23. Bobrov D. S. Politiko-pravovye mekhanizmy osvoeniia Rossiiskim gosudarstvom Verkhnego Ob'-Irtysh'ia (Altaia) v pervoi polovine XVIII v. Diss. kand. ist. nauk [Political and legal mechanisms of the development of the Upper Ob-Irtysh area (Altai) by the Russian state in the first half of the 18th century. Cand. Hist. Sci. Diss.]. Barnaul, 2017, 252.

24. Bobrov D. S. Prikazchiki ostrogov i slobod Verkhnego Priob'ia kak sistemoobrazuiushchie instituty lokal'nogo zvena sistemy upravleniia regionom v 20-30-kh gg. XVIII v. [Bailiffs of the forts and settlements of the Upper $\mathrm{Ob}$ area as the core institutions of local unit within the system of regional management in the 20-30s 
of the XVIII century]. Izvestiia Altaiskogo gosudarstvennogo universiteta = Izvestiya of Altai State University Journal, no. 2 (2016): 33-37. DOI: 10.14258/izvasu(2016)2-04

25. Moiseev V. A. Rossiia i Dzhungarskoe khanstvo v XVIII v. (ocherki vneshnepoliticheskikh otnoshenii) [Russia and Dzungarian khanate in the XVIII century (essays of foreign politic relations)]. Barnaul: Izd-vo AGU, 1998, 174.

26. Bobrov D. S. Kolyvanskie zavody v politike kuznetskikh voevod vo vtoroi chetverti XVIII v. [Kolyvan factories in the policy of the Kuznetsk voivodes in the second quarter of the XVIII century]. Bulletin of Kemerovo State University, no. 4 (2017): 23-29. DOI: 10.21603/2078-8975-2017-4-23-29

27. Bykonia G. F. Zaselenie russkimi Prieniseiskogo kraia v XVIII v. [Russian colonization in Prieniseisky krai in the 18th century]. 2-e izd., dop., osushchestvlennoe po pervoi avtorskoi redaktsii. Krasnoiarsk: KGPU im. V. P. Astaf'eva, 2013. 1 elektron. opt. disk (CD-ROM).

28. Zuev A. S. Shtatnaia reforma sibirskogo kazachestva 1737 g. [Regular reform of the Siberian Cossacks in 1737]. Vestnik Novosibirskogo gosudarstvennogo universiteta. Seriia: istoriia, filologiia = Novosibirsk State University Bulletin. Series: history and philology, no. 6 (2007): 22-27.

29. Minenko N. A. Russkaia krest'ianskaia obshchina v Zapadnoi Sibiri. XVIII-pervaia polovina XIX v. [Russian peasant community in Western Siberia 18th - first half of 19th century]. Novosibirsk: Izd-vo Novosib. un-ta, 1991, 265.

30. Dmitriev A. V. Russkaia reguliarnaia armiia v Sibiri (1725-1796 gg.). Diss. doktora ist. nauk [Russian regular army in Siberia (1725-1796). Dr. Hist. Sci. Diss.]. Novosibirsk, 2018, 439. 